\title{
Cyrano's utopia: where you become what you eat
}

\section{Anne Staquet \\ University of Mons}

\begin{abstract}
The theme of food might seem futile in view of the questions generally addressed by philosophy. However, in Cyrano de Bergerac's utopian novels, Les États et Empires de la Lune and Les États et Empires du Soleil, the theme of food is strongly linked to the author's philosophy. This is certainly related to Cyrano's materialistic position. To the extent that thought is nothing more than a function of the body, one becomes somehow what one eats. In the same way, death is no longer to be considered as the liberation of a soul, but as a physical transformation process of beings: the putrefaction of a being nourishes plants and worms which will feed birds, which themselves will feed certain mammals. Not only does the distinction between man and animal disappear, but the plants themselves acquire the status of sensitive and reasoned beings.
\end{abstract}

Keywords: Cyrano, Cannibalism, Utopia, Materialism

Résumé: La thématique de l'alimentation pourrait paraître futile eu égard aux questions généralement abordées par la philosophie. Or, dans les romans utopiques de Cyrano de Bergerac, Les États et Empires de la Lune et Les États et Empires du Soleil, la thématique de l'alimentation est fortement en lien avec la philosophie même de l'auteur. C'est certainement lié au positionnement matérialiste de Cyrano. Dans la mesure où la pensée n'est rien d'autre qu'une fonction du corps, on devient en quelque sorte ce que l'on mange. De la même manière, la mort n'est plus à considérer comme la libération d'une âme, mais comme un processus physique de transformation des êtres les uns dans les autres : la putréfaction d'un être nourrissant des végétaux et des vers, ceux-ci des oiseaux, qui eux-même nourriront certains mammifères. Non seulement la distinction entre l'homme et l'animal disparaît, mais les végétaux eux-mêmes acquièrent un statut d'être sensibles et raisonnant.

Mots-clé: Cyrano, Cannibalisme, Utopie, Matérialisme 
The theme of food may seem futile in view of the questions generally addressed by philosophy. And to be honest, I first thought it was a theme of no particular relevance, just a subject to feed the academic machine which, as you may have noticed, is becoming more and more voracious. ${ }^{1}$ But I have to admit that I am but a cog in this ogre of a machine. And this, combined with the desire to see friends again at Porto university, led me to look into this question of food from the perspective of an author whom I greatly appreciate: Cyrano de Bergerac. Indeed, in his utopian novels, The States and Empires of the Moon and The States and Empires of the Sun, the theme of food is strongly linked to the author's own philosophy. This is certainly no coincidence. I like $17^{\text {th }}$-century materialist authors and, in a novel, materialism will express itself in an incarnate way. It is therefore very likely that the question of food is closely linked to the philosophy of a materialist thinker and novelist. This being the case, I propose to explain here, by way of a few gastronomic scenes, how these two novels present essential aspects of Cyrano de Bergerac's philosophy.

But before getting to the heart of the matter, a few remarks are in order. Many aspects of Cyrano's philosophy are found in the Other World. The structure of the novel, the various journeys and societies discovered, as well as the many characters (often philosophers) who teach the hero Dyrcona, all facilitate the presentation of a philosophy that is never systematically made explicit. However, we must be careful not to attribute all philosophical discourse to Sieur de Bergerac. In a novel which also tends towards the burlesque, we have less context to guide us, which leaves the contradictions between the component parts of Cyrano's philosophy far more implicit than would be the case if all the concepts had been brought together in a single text. Nevertheless, some ideas are recurrent. Our aim here is not to present a synthesis of Cyrano's philosophy, but to highlight the elements of his thinking in which food plays a role. Three aspects of his philosophy give particular importance to food: materialism, naturalism and equality or continuity between living beings.

At first glance, it is not self-evident that Cyrano's materialism is expressed through food. Indeed, perhaps the most famous episode of the novel is the one in which, in Paradise - which is materialised on the Moon - the hero discovers that meals are only made of fumes 
The narrator expects to receive a solid meal, but finds himself tortured like Tantalus, because at mealtimes he is wreathed in fumes announcing exquisite dishes, but they are one which he can never get his teeth into. However, this is not a particularly refined and strange mode of torture, because in that world, the inhabitants "only live on Steams" (Cyrano de Bergerac 1687: 47). Food therefore passes only through the respiratory tract, as if the smell of food contained everything necessary to satisfy hunger: "Unless you have already lived after this manner, you would never think, that the Nose without Teeth and Gullet, can perform the office of the Mouth, in feeding a Man" (idem: 48). One could therefore imagine a very spiritual and disembodied world where matter takes on an almost non-existent form. The explanation could be consistent with the fact that the interest of such a mode of feeding is the absence of excreta: "by reason that their Food hardly engenders any Excrements, which are in a manner the original of all Diseases" (ibidem). Later in the story, during the journey on the Sun, we learn that digestion is also a cause of fatigue: "[...] Sleep is only produced by the gentle Exhalation of the Victuals, which evaporate from the Stomach to the Brain" (idem: 70).

However, reading these passages alone one could imagine that the Sieur de Bergerac's philosophy might be very disembodied, but all the texts lead to the opposite conclusion. Indeed, on the one hand, the hero obtains food worthy of the name the very next day. Paradise is not without solid food, but it seems to be reserved for animals. When, not really satisfied by the smoke, Dyrcona asks for a more substantial meal, he is offered cooked larks because that is what monkeys eat. ${ }^{2}$ The larks, shot down at that very moment, fall at his feet already cooked and ready to eat. We see through the hero how man is brought back to his animality.

Certainly, for men digestion is absent from Paradise. It is even because of this digestive process that eternal life is impossible. Later in the text, we find a description of what happens when the fruit of the Tree of Life is eaten: "He soon consumed it and exhaled the serpent in smoke". (Cyrano de Bergerac 2004: 69. My translation AS). ${ }^{3}$ This snake is the intestines, which devour all the food we eat every day. His venom is bile, and it is he who eats our corpse in the grave and makes it disappear. By consuming apples, we get rid of 
what devours us from within and nothing stands in the way of eternal life. In contrast to the biblical situation, in the lunar paradise, it is clearly advantageous to eat the apple. The parallel between food and eternal life or knowledge is very clearly established. However, Cyrano shifts the discourse about life and death to the organic terrain: what acts as salvation is not our soul saved from eternal torment, it is the body freed from decay by consuming the sacred fruit, whose taste resembles that of the "spirit of wine" (Cyrano de Bergerac 2004: 70. My translation AS). The only alternative to the constant need to digest food and the ultimate decomposition of the body is to eat the fruit of the Tree of Life: there is therefore no promise of redemption after death and no mention is made of a soul that would survive the body. The inhabitants of Paradise are therefore living beings, possessing a body capable of nourishment, although freed from digestion and death, and this is what they call eternal life.

It should not be believed, moreover, that the issue of the digestion process is thus settled and thereafter does not occupy an important place in the novel. Indeed, it is always the organic and bodily aspects that are put forward, both for food and for salvation, in the biblical sense of the term. The idea of considering the transmission of a beneficial substance to the body in an a priori spiritual context (as is the case when it comes to enjoying eternal life on Paradise) is pushed to its climax in the second part of the story, during Dyrcona's journey on the Sun.

To console Dyrcona after being sentenced to death by birds, it clearly states that in doing so he has a chance of being reborn as his body will be transformed into worms, which will turn into flies and be eaten by birds:

J'ai un secret à te découvrir, mais je ne voudrais pas qu'aucun de mes compagnons eût entendu de ma bouche: c'est qu'étant mangé, comme tu vas l'être, par nos petits oiseaux, tu passeras en leur substance. Oui, tu auras l'honneur de contribuer, quoiqu'aveuglément, aux opérations intellectuelles de nos mouches, et de participer à la gloire, si tu ne raisonnes toi-même, de les faire au moins raisonner. (Cyrano de Bergerac 2004: 250)

[But I have a Secret to discover to thee, which I would not any of my Companions should hear from 
my Mouth, and that is, That being Eaten, as thou art going to be, by our little Birds, thou'lt pass into their Substance; yes, thou'lt have the honour to contribute, though blindly, to the Intellectual operations of our Flyes, and share of this Glory, that if thou reasonest not thy self, thou'lt make them at least to reason]. (Cyrano de Bergerac 1687: 126)

There is also another explanation of this renewal of resurrection to a physiological process during a discussion. A character inhabiting the Sun exposes a theological difficulty to Dyrcona. If a Christian eats a Mohammedan, he assimilates his body into his own, in a mixture of two foreign materials homogenised by a process of digestion. This new substance is even transmitted by its sperm to its offspring. Should God therefore dedicate this hybrid body to bliss or damnation? It seems that this leads to a paradox that even God cannot solve. Everything happens as if faith could be transmitted in this way through these mechanisms of feeding, digestion, assimilation of the characteristics of foreign bodies, as if it were the body alone, and not something immaterial, that could be worthy of gaining Paradise or being damned. If a Christian eats a Muslim, their bodily substances mix so well that they seem to be one in the eyes of God. The difference between the Muslim and the Christian therefore lies more in a disposition of the body than in a characteristic of the soul. This is so much so that it is possible, by this purely organic and ingestion-related process, to place God in an impossible situation: "What would still be very ridiculous is that this body would have deserved Hell and Paradise all together" (Cyrano de Bergerac 2004: 156 My translation AS).

There is therefore a radical form of materialism in Cyrano's thought: everything that exists is of the order of matter. This leads to a process in which the thoughts themselves are linked to the disposition of the organs: "Know then, that to the end I might know your inside, I disposed all the parts of my Body, into the same Order I saw yours in; for being in all parts situated like you, by that disposition of matter, I excite in my self the same thought, that the same disposition of matter raises in you". (Cyrano de Bergerac 1687: 161-62) ${ }^{4}$ Thought is no longer anything other than a particular organisation of matter.

In this conception where everything is material, it is logical that all phenomena can be explained by natural laws. Cyrano's materialism is given in the form of a profound 
naturalism, not in the sense that nature is divinised, but in the sense that nature is the only principle and that all phenomena can find a natural explanation. Thus, all religious myths find another explanation in The States and Empires of the Moon and the Sun. This is particularly the case with the prophet Elijah's chariot of fire, which becomes a sparkling iron chariot, which, through the ingenuity of the character and the properties of iron and magnet, helps to explain the character's ascent to the Moon and Paradise.

If the property of the magnet is not explained in this episode, it is discovered during Dyrcona's visit to the Sun. He then gave an explanation of a mythical nature: the friendship of Pylades and Orestes, in which food plays an important role. However, it would be wrong to conclude that, for Cyrano, the natural or mythological explanations are of the same order, because this will give him the opportunity to explain the legend by bringing it back to physical phenomena. The laws of nature are therefore always the reference.

For example, the Cyranian interpretation of the myth of Pylades and Orestes is as follows. Watching his friend and cousin die, Orestes, inconsolable, expires quickly in turn. Their remains will be buried next to each other and the embracing bodies of the lovers will feed two young shoots. Food once again plays a decisive role. These young shoots will become trees, producing fruit. The lovers' passion was so intense that the one who eats the fruit of one tree will be irresistibly attracted to the one who eats the fruit of the other. As a result, we will see either an unfailing friendship when it comes to people of the same sex, or an eternal love when the victims are male and female. Unfortunately, the principle poses some problems, which Cyrano enjoys exposing in detail. So, when it is a father and a daughter who eat both fruits, it will consummate incest. And we immediately see the perversion that will be created when these fruits are eaten by a goddess and a bull. In other cases, the juice of the two fruits is so sublimated that the two lovers cannot detach themselves from each other and end up forming a hermaphrodite. And the legend of Narcissus also finds an explanation by the same process: the young man ate an abundance of both fruits. As we can see, not only do many myths find alternative explanations, but they always do so on the basis of natural and dietary principles. Regardless of whether the explanation is fanciful and unscientific, the important thing is that the clarifications are 
physical: the putrefaction of the bodies that will serve as soil for young plants and the ingestion of the fruits. It is on this same mythological basis that the author will also explain the properties of iron and magnet. Parents desperate to see their children fall in love with an irrepressible passion for their friends or lovers will burn all these plants. The ashes containing only the quintessence will scatter over the whole earth and form the iron and magnet.

Quite naturally, from a materialistic perspective, there is no reason why man should be at the centre of creation. And, indeed, in these novels, man loses his predominant place. He is only one of many beings left. The hero's desire to go to the Moon is rooted in this idea: he wants to show that, for the inhabitants of the Moon, the Earth is only a Moon. ${ }^{5}$ Nor is man the centre of creation any more than the Earth the centre of the world. Therefore, being only a being like others, he is composed of the same elements as other living beings: "So that it may be said, that all that's necessary for the composition of a Tree, is in a Man; and in a Tree, all that's necessary for making of a Man" (Cyrano de Bergerac 1687: 67). The wording at this stage is still ambiguous. In Aristotle's work, too, the universe is composed of the same elements, including living beings. It is therefore the different souls - vegetative, sensitive and intellective - that distinguish living beings: man possessing the three souls, animals the first two and plants only the first. ${ }^{6}$ The difference in nature disappears entirely in Cyrano and it is the process of food that explains it. Since beings are what they eat, the difference is at most degrees and the passages between beings are very common:

Vous savez, ô mon fils, que de la terre, il se fait un arbre, d'un arbre un pourceau, d'un pourceau un homme. Ne pouvons-nous donc pas croire, puisque tous les êtres en la Nature tendent au plus parfait, qu'ils aspirent à devenir hommes, cette essence étant l'achèvement du plus beau mixte, et le mieux imaginé qu'il soit au monde, étant le seul qui fasse le lien de la vie brutale avec l'angélique? Que ces métamorphoses arrivent, il faut être pédant pour le nier. Ne voyons-nous pas qu'un pommier, par la chaleur de son germe, comme par sa bouche, suce et digère le gazon qui l'environne; qu'un pourceau dévore ce fruit et le fait devenir une partie de soi-même; et qu'un homme, mangeant le pourceau, réchauffe cette chair morte, la joint à soi, et fait enfin revivre cet animal sous une plus noble espèce? (Cyrano de Bergerac 2004: 50) 
[You must know, that the Earth, converting itself into a Tree, from a Tree into a Hog, and from a Hog into a Man, is an Argument, that all things in Nature, aspire to be Men; since that is the most perfect Being, as being a Quintessence, and the best devised Mixture in the World; which alone unites the Animal and Rational Life into one. None but a Pedant will deny me this, when we see that a PlumbTree, by the Heat of its Germ, as by a Mouth, sucks in and digests the Earth that's about it; that a Hog devours the Fruit of this Tree, and converts it into the Substance of itself; and that a Man feeding on that Hog, reconcocts that dead Flesh, unites it to himself, and makes that Animal to revive under a more Noble Species] (Cyrano de Bergerac 1687:129-130)

Certainly, the story here evokes only the evolution towards man. Though man is no more than the top of the food chain, it is not difficult to deduce that this is a two-way process, since excreta and putrefaction also feed the plants. It is, moreover, as we have seen, the secret that a bird will tell Dyrcona about the Sun, to comfort him from his punishment, consisting of being eaten by flies.

Cyrano pushes this process to its extreme consequences: while most corpses are burned, the same cannot be said of philosophers, who are invited to a philosophical banquet of a completely different kind. When a philosopher "comes to an Age, wherein he finds his Wit begin to decay" (idem: 124), he brings together his friends, who have previously fasted. He then draws a dagger and, one after the other, each of his friends "sucks down his Blood, till a Second succeed him, then a Third, Fourth, and so all the Company" (idem:125). They will then devote themselves to the pleasures of love with fertile young girls, so that "if from an Hundred Embracements anything Spring, they may be assured it is their old Friend Revived" (idem:126). Since we are what we eat and there is no discontinuity between species, it is indeed logical that cannibalism is not a taboo, but a transformation process like any other.

The conclusion is explicit: we can no longer imagine a real distinction between animals and humans:

Quoi! Me répliqua-t-il en s'éclatant de rire, vous estimez votre âme immortelle privativement à celle des bêtes? Sans mentir, mon grand ami, votre orgueil est bien insolent! Et d'où argumentez-vous, je vous prie, cette immortalité au préjudice de celle des bêtes? En premier lieu, je vous le nie, et je vous 
prouverai, quand il vous plaira, qu'elles raisonnent comme nous. (Cyrano de Bergerac 2004: 148)

[What?! What?! He replied, bursting out laughing, you consider your immortal soul as something that beasts don't have? Honestly, my dear friend, your pride is so very insolent! And how can you argue, please, that you may have immortality but animals cannot? First of all, I deny it and I will prove to you, whenever you like, that they reason just as we do.] (My translation, AS)

The instructor's argument here is made by means of ad hominem theological reasoning: if God is right, the fact that he has given reason to single men would imply that it is to other beings that he grants immortality. There is no longer any distinction of nature to distinguish the living.

And Cyrano pushes the idea to its most radical consequences: it is not only between humans and animals that differences are erased, this also applies to plants, ${ }^{7}$ as he shows with cabbage.

De dire pourtant que Dieu a plus aimé l'homme que le chou, c'est que nous nous chatouillons pour nous faire rire: étant incapable de passion, il ne saurait ni haïr ni aimer personne; et, s'il était susceptible d'amour, il aurait plutôt des tendresses pour ce chou que vous tenez, qui ne saurait l'offenser, que pour cet homme dont il a déjà devant les yeux les injures qu'il lui doit faire. (Cyrano de Bergerac 2004: 112)

[Yet the Opinion that Nature is kinder to Mankind, than to Cabbage kind,[it] tickles [us] and makes us laugh: But seeing she is incapable of Passion, she can neither love, nor hate anything; and were she susceptible of Love, she would rather bestow her affection upon this Cabbage, which you grant cannot offend her, than upon that Man who would destroy her, if it lay in his power] (Cyrano de Bergerac 1687: 94)

The cabbage is presented as a creature of God in the same way as any animal or human being: "[...] Is not that Cabbage you speak of, a Being existent in Nature, as well as you?" (idem:93). Worse still, it would be more serious to kill a cabbage than a man, because while man is promised resurrection, this is not the case with a cabbage: killing it therefore amounts to taking its life forever and without hope of salvation. The life of the cabbage is 
therefore more precious than that of a human and it is its privileged status that gives man more responsibility towards other creatures of God. But this inversion of the food chain, where the predator finds himself responsible for the misfortune of the food, goes as far as to erase the supposedly privileged status of man in creation:

Dira-t-on que nous sommes faits à l'image du Souverain Être, et non pas les choux [...] Si donc notre âme n'est plus son portrait, nous ne lui ressemblons pas davantage par les mains, par les pieds, par la bouche, par le front et par les oreilles, que le chou par ses feuilles, par ses fleurs, par sa tige, par son trognon, et par sa tête. (Cyrano de Bergerac 2004: 122)

[If it be said, that we are made after the Image of the Supreme Being [...]. If then our Soul be no longer his Image, we resemble him no more in our Feet, Hands, Mouth, Forehead and Ears, than a Cabbage in its Leaves, Flowers, Stalk, Pith, and Head] (Cyrano de Bergerac 1687:95)

The blurring of the distinction between human and cabbage, or any other being of creation, finds a perfect place in Cyrano's materialistic system, whose discourse on food was only one illustration among many: a man eating a cabbage and assimilating it makes it indistinguishable in the eyes of God, as it was with the Muslim. There is therefore no longer any reason to maintain a clear difference between these entities and references to reason and immortality are only ad hominem arguments. Moreover, since all beings are composed of the same elements and thought is nothing but a particular organisation of matter, there is nothing to prevent us from assuming that plants reason.

Cyrano's naturalism does not require the explanations to be purely scientific or necessarily in accordance with the scientific knowledge of the time. What characterises his thinking is to give all phenomena - human as well as physical - an explanation through the principles of nature. Of these principles, the principle of food has a privileged place, because it is at the origin of transformation and equality between beings. At Cyrano's, we are what we eat. 


\section{NOTES}

${ }^{1}$ This is what Hesse calls the "Age of the Feuilleton" meaning the age of serial stories.

2 Throughout his journey, except for the kingdom of birds where, amusingly, he was forced to pretend to be a monkey to save his life, Dyrcona was not considered a man, that is, a being endowed with reason.

${ }^{3}$ I provide my own translation, labelled AS, for Anne Staquet, whenever Lovell's version is not faithful to the source text.

${ }^{4}$ It is the same teaching that Socrates' demon gave to Campanella: "[...] it was I that advised him, whilst he was in the Inquisition at Rome, to put his Face and Body into the usual Postures of those, whose Inside he needed to know, that by the same frame of Body, he might excite in himself, the thoughts which the same scituation had raised in his Adversaries." (Cyrano de Bergerac 1687: 37).

5 "Et moi, dis-je, qui souhaite mêler mes enthousiasmes aux vôtres, je crois, sans m'amuser aux imaginations pointues dont vous chatouillez le temps pour le faire marcher plus vite, que la Lune est un monde comme celui-ci, à qui le nôtre sert de lune." [And for my part, Gentlemen, said I, that I may put in for a share, and guess with the rest; not to amuse my self with those curious Notions, wherewith you tickle and spur on slow/paced Time; I believe, that the Moon is a World like ours, to which this of ours serves likewise for a Moon.] (Cyrano de Bergerac 1687: 2).

${ }^{6}$ It should be noted that it is possible for a soul to be added or lost, but these are exceptional cases and they do not allow us to consider that there is a true continuity in the living.

7 If the author had simply established, as is usually the case, continuity between humans and animals, this could have led to a solution of the vegetarian type. However, this path is totally closed since plants themselves are considered as important living beings in the same way as humans and animals. 


\section{Works Cited}

Bergerac, Cyrano de (2004), Les États et Empires de la Lune et Les États et Empires du Soleil, Jacques Prévot (éd.), Paris, Folio, 2004.

-- (1687), The Comical History of the States and Empires of the Worlds of the Moon and the Sun, trans. A. Lovell, A.M., London, printed for Henry Rhodes, next door to the Swan-Tavern, near Bride-Lane, in Fleet-Street.

https://quod.lib.umich.edu/e/eebo2/A35530.0001.001?view=toc [last accessed on 15 september 2019].

Hesse, Hermann (1943), Magister Ludi. The Glass Bead Game, trans. Richard and Clard Wiston. https://www.starcenter.com/glassbead.pdf [last accessed on 15 September 2019].

Anne Staquet holds a PhD in philosophy from Laval University (Canada) and an Aggregation of Higher Education from ULB. She is a professor at the University of Mons, where she heads the Department of Philosophy and History of Science. She has published seven philosophical essays, one novel, one play and more than a hundred articles. His main works are: La morale et ses fables. De l'éthique narrative à l'éthique de la souveraineté, L'utopie ou les fictions subversives, Descartes et le libertinage, La ruse du Léviathan, Cyrano sens dessus dessous and Descartes avance-t-il masqué ? 